\title{
'Marginalia' by die teologie van Natie van Wyk
}

\begin{tabular}{|c|c|}
\hline $\begin{array}{l}\text { Author: } \\
\text { Wim A. Dreye }\end{array}$ & ${ }^{1}$ (1) \\
\hline $\begin{array}{l}\text { Affiliation: } \\
{ }^{1} \text { Department } \\
\text { and Church P } \\
\text { of Theology a } \\
\text { University of } \\
\text { South Africa }\end{array}$ & $\begin{array}{l}\text { Church History } \\
\text { lity, Faculty } \\
\text { a Religion, } \\
\text { retoria, }\end{array}$ \\
\hline $\begin{array}{l}\text { Research Proj } \\
\text { Project Leade } \\
\text { Project Numb }\end{array}$ & $\begin{array}{l}\text { ct Registration: } \\
\text { r: Wim Dreyer } \\
\text { er: } 77370920\end{array}$ \\
\hline $\begin{array}{l}\text { Description: } \\
\text { This research } \\
\text { project, 'Justi } \\
\text { Dignity. A Ref } \\
\text { perspective', } \\
\text { Wim Dreyer, } \\
\text { Church Histor } \\
\text { Polity, Faculty } \\
\text { University of }\end{array}$ & $\begin{array}{l}\text { s part of the } \\
\text { e and Human } \\
\text { rmed } \\
\text { lirected by Dr } \\
\text { epartment of } \\
\text { and Church } \\
\text { of Theology, } \\
\text { retoria. }\end{array}$ \\
\hline $\begin{array}{l}\text { Correspondin } \\
\text { Wim Dreyer, } \\
\text { wim.dreyer@ }\end{array}$ & $\begin{array}{l}\text { g author: } \\
\text { up.ac.za }\end{array}$ \\
\hline $\begin{array}{l}\text { Dates: } \\
\text { Received: } 01 \\
\text { Accepted: } 14 \\
\text { Published: } 15\end{array}$ & $\begin{array}{l}\text { ug. } 2018 \\
\text { Aug. } 2018 \\
\text { Nov. } 2018\end{array}$ \\
\hline $\begin{array}{l}\text { How to cite th } \\
\text { Dreyer, W.A., } \\
\text { "“Marginalia” } \\
\text { van Natie van } \\
\text { Teologiese Stu } \\
\text { Theological St } \\
\text { a5209. https:/ } \\
\text { 10.4102/hts.v }\end{array}$ & $\begin{array}{l}\text { is article: } \\
\text { 2018, } \\
\text { by die teologie } \\
\text { Wyk', HTS } \\
\text { dies/ } \\
\text { udies 74(4), } \\
\text { /doi.org/ } \\
74 i 4.5209\end{array}$ \\
\hline $\begin{array}{l}\text { Copyright: } \\
\text { (C) 2018. The } \\
\text { Licensee: AOS } \\
\text { is licensed un } \\
\text { Creative Com } \\
\text { Attribution Lic }\end{array}$ & $\begin{array}{l}\text { uthors. } \\
\text { IS. This work } \\
\text { ler the } \\
\text { nons } \\
\text { ense. }\end{array}$ \\
\hline Read online: & \\
\hline 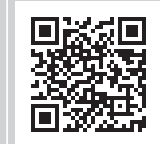 & $\begin{array}{l}\text { Scan this QR } \\
\text { code with your } \\
\text { smart phone or } \\
\text { mobile device } \\
\text { to read online. }\end{array}$ \\
\hline
\end{tabular}

'Marginalia' are notes made in the margins of a book. It could be general comments, glosses (interpretation of the meaning of a phrase) or scholia (commentary on the text). For centuries marginalia was considered an important scholarly activity, almost as important as the original text. The famous marginalia on the text of Homer's Iliad dates back to the 5th century before Christ. Some of the most important theologians in history kept themselves busy by adding marginalia to texts. Luther's marginalia on the text of Paul's Letter to the Romans is a good example of this type of scholarly endeavour. Writing about the life and work of a fellow theologian could at best be a few marginal notes - sometimes it is a mere scribble, sometimes an interpretation of a text and sometimes commentary is necessary. This contribution reflects on the life and work of I.W.C. van Wyk, a theologian who dedicated his life to the church, mission and reformed theology.

\section{Inleidende opmerkings}

By die emeritaat van 'n gewaardeerde kollega soos Natie van Wyk, is dit gepas om te begin met 'n anekdote. Ek het hom beter leer ken toe ons albei by die sendingwerk van die Nederduitsch Hervormde Kerk van Afrika (NHKA) betrokke was. Ek is in 2005 in die sinodale sendingkantoor aangestel; hy was sedert 1996 as dosent verantwoordelik vir die teologiese opleiding van die Maranatha Reformed Church of Christ se studente en predikante. Dit het meegebring dat ons dikwels in gesprek was oor teologie. Sy wye kennis van Lutherse en Calvinistiese teologie het sonder uitsondering bygedra tot prikkelende en leersame gesprekke. Die gesprekke het dikwels oor die kerk, sending en reformatoriese teologie gehandel. Tans is ons steeds ten nouste betrokke by gesamentlike navorsingsprojekte oor reformatoriese teologie. Dit is en bly 'n voorreg om Natie van Wyk as assosiaat en kollega te ken.

Van Wyk se teologiese bydrae is wyd en diep. Terwyl dit onmoontlik is om in die bestek van een artikel reg te laat geskied aan sy teologiese bydrae, het ek gekies om enkele marginalia onder drie opskrifte te struktureer, te wete reformatoriese teologie, sending en die kerk. Die keuse was eintlik maklik, omdat ek weet dat hierdie temas na aan sy hart is; eintlik deel van sy menswees is.

Prof. dr Ignatius William Charles (Natie) van Wyk is op 28 September 1953 in Johannesburg gebore. Hy is getroud met prof. dr Neltjie van Wyk, verbonde aan die Mediese Fakulteit (Universiteit van Pretoria). Uit dié huwelik is twee seuns (Gert en Naas) gebore - maar dit het ook op akademiese terrein vrug gedra. Van Wyk het verskeie artikels op die terrein van die mediese etiek, gesondheidsorg in Afrika, menslike lyding en die teodisee probleem gepubliseer (sien byvoorbeeld Van Wyk 1988; 2009a; 2009b).

Sy akademiese opleiding het soos volg verloop:

- 1977, BA Admissie (RAU).

- 1979, BA (Hons) Wysbegeerte (UP - met lof).

- 1980, BD (UP - met lof).

- 1981, Doktorale Eksamens (UP - met lof).

- 1981-1984, Studeer sistematiese teologie onder Gerhard Sauter in Bonn, Eberhard Jüngel in Tübingen en Berthold Klappert in Wuppertal.

- 1987, Promoveer met 'n proefskrif met die titel: 'Das Theodizeeproblem als Orienterungspunkt der kirchenpolitischen und theologische Streitfragen: Eine Auseinandersetzung mit Jürgen Moltmann'.

Van Wyk is op 13 Januarie 1980 in Gemeente Edenvale as predikant van die NHKA georden. Daarna het hy ook in Bloemfontein-Wes as predikant gedien. Hy het in talle rade en komitees van die NHKA gedien. Dit was veral met sy betrokkenheid by die Raad vir Apostolaat en die Raad vir Kerkregtelike Advies waar hy 'n enorme bydrae gelewer het, onder andere met die opstel van die Kerkorde van 1997 (NHKA 1997). Dáár het hy konsekwent daarvoor gestry dat die rasseklousule (Artikel III) uit die Kerkorde verwyder word. 
Van 1996 tot 2004 dien hy eers as hoof van die Hervormde Teologiese Opleiding (HTO) te Hammanskraal, en vanaf 2005 tot 2015 as direkteur van die Afrika Instituut vir Missiologie (AIM). Hy het ook by geleentheid aan die Fakulteit Teologie en die Hervormde Teologiese Kollege (aan die Universiteit van Pretoria) lesings in Dogmatiek en Christelike Etiek aangebied. Sedert 2016 werk hy as Koördineerder van Ekumeniese Sake, met die fokus op Reformasie 500. Met die herdenking van die Kerkhervorming deur die Afrikaanse susterskerke, het hy 'n besondere bydrae gelewer deur middel van navorsing, die beskikbaarmaking van materiaal en die inrigting van die gesamentlike feesdiens op 29 Oktober 2017 in Pretoria. Dit was die kulminasie van jarelange betrokkenheid by ekumeniese liggame soos die Tussenkerklike Raad en bilaterale gesprekke. In daardie opsig is Van Wyk ook 'n ekumeniese teoloog.

Van Wyk was redakteur van twee teologiese tydskrifte, te wete Theology and the Church in South Africa (ThaciSA) asook die Tydskrif vir Hervormde Teologie (THT). Hy het deur die inrigting van dié tydskrifte talle jonger akademici aangemoedig en geïnspireer om te publiseer, veral op die terrein reformatoriese teologie. Die jaarlikse konferensies wat hy aanbied onder die vaandel van die Hervormde Teologiese Kollege het jong akademici die geleentheid gebied om lesings oor Ebeling, Moltmann, Pannenberg en vele ander aktuele temas aan te bied. Hy was seksie-redakteur van die Hervormde Teologiese Studies (HTS) se Reformasie 500 herdenkingsuitgawe (Van Wyk 2017c).

Van Wyk het as gasdosent lesings in Swede, Ghana, Duitsland en Nederland aangebied. Hy is lid van die Luther-Gesellschaft (Wittenberg), Karl Barth Studienverein (Bonn), Southern African Missiological Society, asook die Calvyn Navorsingsvereniging.

Vervolgens, enkele marginalia by die teologie van I.W.C. van Wyk, in die volgorde van reformatoriese teologie, sending en kerk. Dit kan hoogstens eksemplaries geskied, waar enkele tekste aan die orde gestel word wat iets van sy teologiese nadenke verwoord.

\section{Reformatoriese teologie}

Natie van Wyk se teologie kan beskryf word as Bybelsreformatories, en meer spesifiek kerklik-evangelies. Dit is opsigtelik dat hy homself nie beperk tot Lutherse óf Calvinistiese teologie nie. Sy teologie is eerder 'reformatories' van aard, dus inklusief en genuanseerd. In daardie opsig staan hy in die tradisie van Hervormde teologie in SuidAfrika, wat getipeer word as 'Bybels-reformatoriese teologie' in teenstelling met óf Gereformeerde óf Lutherse teologie. Van Wyk (2013:1) praat self van Bybels-reformatoriese teologie, maar omskryf dit as 'n 'evangeliese teologie'. Van Wyk se teologie oriënteer aan vier uitgangspunte, te wete die Woord van God, die breë reformatoriese tradisie, die kerk, maar veral die evangeliese aard van die Christelike teologie.

'n Verdere aspek van sy teologiese bydrae is dat dit diensbaar moet wees aan die Afrikaanse kerke en teologie. Met die 500-jarige herdenking van die Kerkhervorming het Van Wyk, op versoek van die redaksie van die HTS Teologiese Studies, as redakteur van 'n supplementum opgetree onder die titel: Nadenke oor 500 jaar Reformatoriese teologie (Van Wyk 2017a). In die inleidende artikel (Van Wyk 2017b:3) skryf hy: 'Die 500-jarige jubileum is die ideale geleentheid om 'n bydrae te lewer tot 'n Afrikaanse Luther-resepsie.' Hy is een van die baie min Afrikaanse teoloë wat homself deurlopend met Lutherse teologie besig hou. Sy artikels oor Luther, Melanchthon, Bultmann, Ebeling en Pannenberg is omvangryk.

In sy skryfwerk is Van Wyk doelbewus ingestel op die ontsluiting van oorspronklike tekste (veral Latyn en Duits) vir die Afrikaanse lesers. Hy het 'n hekel aan teoloë wat nie die moeite doen om oorspronklike tekste te lees nie en net staatmaak op sekondêre bronne. Die wyse waarop Van Wyk die Duitse en Latynse tekste in sy publikasies inkorporeer, is opmerklik. Dit beteken dat (Afrikaanse) lesers die oorspronklike outeur se woorde en gedagtegang kan volg (sien as voorbeeld hiervan Van Wyk 2017b; 2017c). Dit is nie net Lutherse teoloë wat só ontsluit word nie, maar ook Calvyn, Barth en Moltmann.

In terme van algemene temas, gee hy onder andere aandag aan die reformatoriese verstaan van die regverdigingsleer, eindoordeel, Christelike vryheid, kuns asook die teodisee problematiek.

Vir die doeleindes van hierdie bydrae volstaan ek met een tema in Van Wyk se bydrae tot reformatoriese teologie, te wete 'Christelike vryheid'. In 'n resente artikel wys Van Wyk daarop dat 'vryheid' 'n tema is wat herhaaldelik in die Nuwe Testament aan die orde kom; daarom het die reformatore ook breedvoerig daaraan aandag gegee (Van Wyk 2017c:22). Dit het ook deur die loop van die twintigste eeu in talle teoloë se werk neerslag gevind. Van Wyk haal Gerhard Ebeling in dié verband aan: 'Der Reformation gedenken, heisst der Freiheit gedenken' (bl. 23). Die aktualiteit van die tema binne die SuidAfrikaanse konteks is vanselfsprekend, veral wanneer dit in gedagte gehou word dat Christelike vryheid raakvlakke het met gewetensvryheid, akademiese vryheid, politieke vryheid en godsdiensvryheid.

Van Wyk is van mening dat 'evangeliese vryheid' nie net 'n sentrale tema in die teologie van Luther is nie, maar ook tiperend van sy menswees en persoonlike lewe was (Van Wyk 2017c:23). Dit blyk uit die feit dat Luther self sy naam verander het na 'Frater Martinus Eleutherius Luther' - Broeder Maartin Luther, verteenwoordiger van die vryheid (Van Wyk 2017c:24). Dit is daarom nie vreemd dat een van die eerste van Luther se hoofwerke oor die 'Vryheid van die Christenmens' handel nie. Dit gaan vir Luther nie net om die mens wat vry is nie, maar hoe die Christenmens in vryheid handel. Laasgenoemde lei daartoe dat Luther voortdurend die spanning tussen vryheid en diensbaarheid handhaaf: Die Christenmens is vry teenoor alle mense en is niemand iets verskuldig nie; die Christenmens is tegelykertyd aan alle mense onderdanig en almal se dienaar. Hierdie dialektiek in 
Luther se denke is fundamenteel belangrik vir die verhouding met die medemens.

Van Wyk (2017c:35) kom tot die gevolgtrekking dat beide Luther en Calvyn 'vryheid' vanuit die regverdigingsleer benader, en daarom is dit 'n essensiële aspek van die Christelike geloof. Beide meen dat die Christenmens, wat iets van die Christelike vryheid verstaan, die liefdesgebod sal nakom en diensbaar sal wees aan hulle medemens en die gemeenskap. Christelike vryheid is krities belangrik, veral in die huidige tydsgewrig. Hy toon, met voorbeelde uit Duitsland en Denemarke, aan hoe die huidige demokratiese bestel in dié lande voortgevloei het uit die reformatoriese verstaan van vryheid (bl. 36-37). Van Wyk (in aansluiting by Jüngel; sien Van Wyk 2017c:36-37) is van mening dat dit nie die taak van reformatoriese teologie is om aan tekste wat oor Christelike vryheid handel betekenis te gee nie; dit kry opsigself betekenis. Dit is eerder die roeping van reformatoriese teoloë om in die publieke sfeer die tekste bekend te stel en as Christen, op grond van die Woord, oor vryheid te praat.

Van Wyk se navorsing is nie beperk tot die sestiende eeu nie, maar hy gee dikwels aandag aan reformatoriese teologie soos dit in die twintigste eeu manifesteer. Om by die reeds vermelde tema van 'Christelike vryheid' te bly, kan maar net verwys word na sy publikasie oor 'Rudolf Bultmann se verstaan van vryheid' (Van Wyk 2015a). Hy skryf soos volg:

Rudolf Bultmann het as toegewyde Lutheraan, op voetspoor van sy geestelike vader(s), die Pauliniese regverdigingsleer, as leer oor die vryheid, in 1948 vir sy eie generasie verduidelik. In die daaropvolgende jare het Bultmann meermale na die vryheidstema teruggekeer om die kultureel politieke en geesteshistoriese belangrikheid van die Christelike vryheidsverstaan te verduidelik. (bl. 2)

Hoewel Bultmann op 'n positiewe wyse vryheid aan genade verbind, is Van Wyk krities oor die feit dat Bultmann te min maak van diensbaarheid wat daaruit voortvloei (Van Wyk 2015a:4). Ook hier merk ons dat Van Wyk deurlopend die diensbaarheid van die Christenmens beklemtoon. Elke Christenmens staan verantwoordelik teenoor God en medemens om God en ons naaste lief te hê en te dien. Hy hamer daarop dat 'genade nooit goedkoop genade is nie'.

Uit hierdie enkele kursoriese opmerkings is dit duidelik dat Van Wyk nie net erns maak om die reformatoriese teologie in en deur die brontekste te ontsluit nie, maar ook aan te toon dat dit steeds in die Suid-Afrikaanse konteks relevant is. Inteendeel, Van Wyk betrek ('engages') voortdurend die SuidAfrikaanse konteks in sy teologiese nadenke. Dit geld nie net vir die konteks van die Afrikaanse kerke nie, maar ook die Afrika-konteks. Byvoorbeeld, Van Wyk verwys (in aansluiting by Masega, Sundermeier en Nürnberger) na die waarde van die Christelike vryheid as teenwig vir die fatalisme wat mense uitlewer aan 'n wispelturige noodlot, opmerklik in talle Afrika-godsdienste (Van Wyk 2015a:5). Só kom Bultmann aan die woord in konteks van die voorvadergeloof!

\section{Sending}

Van Wyk se teologie en kerklike werk is ten nouste verbonde met die Maranatha Reformed Church of Christ, wat tot stand gekom het deur die NHKA se sendingwerk. Die impuls hiervoor was ds. Andrew Mhlaba van die Free Church of Scotland wat in 1928 besluit het om saam met 400 gemeentelede aansluiting te vind by die NHKA. Mhlaba was ontevrede dat die Skotse kerk lekepredikers toestemming gegee het om ook die sakramente te bedien. Op 07 November 1929 het die Hervormde Zending Genootschap tot stand gekom om die gemeente in Lufafa te ondersteun. Die voorsitter van die sendingvereniging was die bekende Bybelvertaler, dr H.C.M. Fourie.

Tydens die 47e Algemene Kerkvergadering (1945) het die NHKA besluit dat sendingwerk nie die taak van 'n vereniging is nie, maar van die kerk self. Die sendingvereniging is ontbind en 'n komitee is aangewys wat voortaan die verantwoordelikheid vir die kerk se sendingwerk sou aanvaar. Die 50e AKV het in 1954 'n nuwe komitee aangewys met prof. dr P.S. Dreyer as voorsitter. Onder sy leiding is die komitee omskep in 'n Sendingraad, wat oor die volgende 30 jaar instrumenteel was in die vestiging van meer as 100 gemeentes in swart gemeenskappe regoor Suid-Afrika.

Die Sendingraad het onmiddellik begin met die opleiding van predikante vir die sendingkerk. Die opleiding is aanvanklik deur P.S. Dreyer behartig by die sinodale kantore van die NHKA. Deur die loop van 1961, is die opleiding na die Universiteit van die Noorde verskuif, waar prof. dr H.P. Wolmarans die leiding geneem het. As gevolg van die politieke onrus en die stryd teen apartheid op die kampus is daar besluit om die opleiding weer te verskuif. Op 03 Maart 1986 het P.S. Dreyer 'n nuwe kampus vir die Hervormde Teologiese Opleiding (HTO) te Hammanskraal geopen. Dit is hier waar Van Wyk in 1993 aangestel is as dosent in Dogmatiek en Christelike Etiek, en in 1996 as Hoof van die HTO.

Onder leiding van Natie van Wyk is die HTO in 2005 getransformeer tot die Afrika Instituut vir Missiologie (AIM), waarvan hy as direkteur gedien het. Intussen is die AIM weereens verskuiwe, terug na waar dit begin het - by die sinodale kantore van die NHKA. Die opleiding wat die AIM aangebied het, is deur die Universiteit van Pretoria erken sodat die studente ' $n$ diploma en honneursgraad van die Universiteit ontvang het. AIM is deur die loop van 2015 gesluit, toe besluit is dat die studente van die MRCC in die toekoms hulle opleiding aan die Universiteit van Pretoria sal voltooi.

Oor 'n periode van 60 jaar (1955 tot 2015) het die NHKA deur middel van die HTO en AIM meer as 200 predikante opgelei vir dienswerk in die MRCC. Verskeie van hierdie studente het studies op magister- en doktorale vlak voltooi. Sommige dien tans as teologiese dosente by UNISA (byvoorbeeld prof. dr M.J. Manala). Van Wyk was vir 22 jaar direk betrokke by die opleiding en begeleiding van ongeveer 
200 teologiese studente. Op daardie wyse het hy 'n massiewe bydrae gelewer tot die kerk se sendingwerk, die groei van die MRCC en die bemagtiging van groot getalle studente afkomstig uit swart gemeenskappe.

Deur die loop van 2007 het Van Wyk begin om navorsing te doen oor kerkgroei in swart gemeenskappe. ${ }^{1}$ Deur middel van empiriese navorsing en vraelyste is belangrike inligting versamel. Enkele gevolgtrekkings is gemaak:

- Die effek van 'n postmoderne samelewing is selfs in plattelandse gemeenskappe sigbaar. Diversiteit, mobiliteit, groter vryheid, beskikbare tegnologie en toegang tot inligting is toenemend beskikbaar. Daarmee saam stel verstedeliking en sekularisasie besondere eise aan die bediening van die evangelie.

- Armoede en werkloosheid (tot 90\% in sommige plattelandse gemeenskappe) beteken dat die kerk arm is. Dit bemoeilik die diakonale werk van die kerk. Dit stel besondere eise aan die teologiese opleiding, om kontekstueel en relevant te wees.

- Tradisionele reformatoriese kerke vind dit moeilik om in gemeenskappe te werk waar tradisionele godsdiens en die verering van die voorvaders steeds belangrik is. 'n Sentrale teologiese vraag is tot watter mate die tradisionele opvattings geakkommodeer kan word, onder andere inisiasie rites, die tradisionele Nuwejaarfees op 21 September, en die onthulling en wyding van grafstene.

- Daar is 'n groot tekort aan effektiewe leierskap in veral plattelandse gemeenskappe. Die kerk het 'n besondere roeping om leierskap te ontwikkel en ook leiding te neem in die gemeenskap. In 'n samelewing wat vinnig verander en voor reuse uitdagings staan, is die opgeleide predikant en/of teoloog in 'n unieke posisie om 'n leidinggewende rol te speel.

- Die navorsing het aangetoon dat die gemeentes in swart gemeenskappe baie vinnig in 'n tradisionele pastorale bedieningsmodel gevestig raak, met die gevolg dat die missionale bewussyn en roeping op die agtergrond skuif. Die bediening fokus tipies op die erediens op Sondag en die pastorale versorging van lidmate. Ampte is ook belangrik, veral die predikant, met die gevolg dat die bediening deur lidmate verwaarloos word.

Kerke in Afrika staan voor enorme uitdagings in terme van werkloosheid, armoede, gebrekkige leierskap en die onvermoë om 'n missionale bedieningspraktyk vol te hou. Dit stel uiteraard besondere eise aan die opleiding van teologiese studente wat in tradisionele gemeenskappe diensbaar moet wees. Van Wyk het in sy navorsing en doseerwerk pertinent hieraan aandag gegee. Hy het in verskeie publikasies aandag gegee aan aktuele vraagstukke relevant tot die konteks en gemeenskappe waarin die MRCC werk.

Een voorbeeld hiervan is 'n artikel waarin hy vanuit 'n reformatoriese perspektief aandag gee aan Jesus as geneser,

1.Die inligting wat hier verskaf word, kom uit my persoonlike argief, omdat ek indertyd by die navorsing betrokke was. maar meer spesifiek binne die Afrika-konteks (Van Wyk 2011). Van Wyk wys daarop dat die voorpase Jesus as 'n geneser verstaan moet word en dat genesings 'n belangrike deel van Jesus se bediening uitgemaak het (Van Wyk 2011:1). Dit is opmerklik dat, in die Europese konteks, Jesus se genesings en wonders betreklik min aandag geniet, maar dat dit in die Afrika-konteks van groot belang is. Genesing was ook 'n belangrike deel van die apostels se missionêre bediening. Deur die eeue was die kerk'n helende gemeenskap, waar siekes versorg word en vir genesing gebid word. Die kerklike diakonaat was instrumenteel in die vestiging van hospitale en verpleging as beroep. Van Wyk (2011:2), met verwysing na Oehmig, Sievernich en Manala, skryf soos volg:

It is noteworthy that at least two of the leading Reformers of the 16th century, namely Philipp Melanchthon and John Calvin, made valuable contributions to the question concerning the relationship between faith and healing. Melanchthon deserves special acknowledgement for paving the way for the close relationship between faith and scientifically tested medicine as well as for the cooperation between the faculties of Theology and Medicine in Wittenberg. Since the Reformation, European churches have had no difficulty in combining mission and 'Western scientific medicine'. 'Medical missions' proved to be a successful missionary approach in Africa. However, one should concede that this approach has also become one of the major stumbling blocks of Reformed mission in Africa. African people welcome the efforts of mainline Protestant churches to enhance health with the support of 'Western scientific medicine'. However, they do not regard this campaign as being sufficient. They also want to experience an alliance with traditional African medicine and healing practices. The urge is for a more holistic approach that would deal with all the African health problems, including witchcraft, spiritual affliction and the typical African stress-related sicknesses. The exclusion of traditional healing practices as well as the traditional African world view from mission has undoubtedly become a stumbling block to African Christianity... I am therefore of the opinion that Reformed mission could continue to transfer elements of European medical achievements (inter alia as fruits of the biblical message) to Africa but that it should also try to liaise with traditional healing ... Bultmann, who was deeply influenced by modernism, had a deprecatory attitude towards faith healing and miracles. His opinions are not helpful in the African context. Africans have little difficulty believing in the supernatural, spirits, miracles and magic. As South Africans living in a country where the First and Third worlds meet, we cannot opt for either the one or the other paradigm. We need a midway of dealing with the biblical reports and our scientific and traditional environments. (bl. 2-3)

Met verwysing na verskeie Afrika-teoloë (bl. 4-5), behandel Van Wyk genesing en die beeld van Jesus as geneser in Afrika-teologie. Hy bespreek die moontlikheid hoe Jesus as geneser en tradisionele genesers met mekaar in verband gebring kan word. Dit is duidelik dat Van Wyk poog om 'n brug te slaan tussen tradisionele Westerse en Afrikabenaderings tot teologiese en geloofsvraagstukke. Lank voordat 'dekolonisasie' en 'Afrikanisering' modewoorde geword het, was Van Wyk, vanweë die konteks waarin hy hom bevind het, besig om reformatoriese teologie te herinterpreteer en toepaslik te maak vir Afrika. Hierdie 
bereidheid om ook na stemme uit Afrika te luister, het daartoe bygedra dat hy oor 'n lang tyd teologiese studente op 'n sinvolle wyse kon begelei en toerus vir hulle dienswerk in swart gemeenskappe.

\section{Die kerk}

Van Wyk se bydrae oor die kerk lê verspreid in talle populêre artikels, kerklike tydskrifte, memoranda, adviese aan kerklike vergaderings en wetenskaplike publikasies. Hy het talle praktiese vraagstukke waarmee die kerk worstel, aangespreek. Voorbeelde hiervan is temas soos oop en geslote eredienste, liturgie, skuldbelydenis oor apartheid, sosiopolitieke en maatskaplike kwessies van die tyd, en meer formeel, ekklesiologie asook die twee-ryke leer.

Van Wyk se kritiese houding teenoor die dominante ekklesiologie wat so invloedryk in die NHKA was, kom duidelik na vore in 'n opstel in 20ste Eeu Hervormde Teologie (Van Wyk 1999:270-285). In sy analise van die NHKA se ekklesiologie, kom hy tot die gevolgtrekking dat dit 'n sterk antropologiese onderbou gehad het en 'beslissend deur 'n bepaalde vryheidsbegrip beïnloed' is (Van Wyk 1999:271). Menswees is verstaan as Afrikaner-wees. Die Afrikaner se strewe na politieke vryheid was dus van die begin bepalend vir die wyse waarop die NHKA oor haarself gedink het. Dit het duidelik tot uitdrukking gekom in die verskeie uitgawes van die Kerkwet en Kerkorde waarin die NHKA pertinent as 'volkskerk' beskryf word. Hierdie formulering is eers tydens die Algemene Kerkvergadering (AKV) van 2016 uit die Kerkorde verwyder. Dit is gedoen op grond van formulerings wat deur die Komitee vir die Herskrywing van die Kerkorde voorgestel is, waar Van Wyk'n leidinggewende rol gespeel het.

Van Wyk se kritiek word nog skerper wanneer hy praat van die Afrikaner se obsessie om sy eie uniekheid en vryheid teenoor ander te handhaaf. Dit het daartoe gelei dat Afrikaners 'vry wil wees om [met ander mense] te doen wat hy wil en soos hy wil' (Van Wyk 1999:271). Dit het daartoe gelei dat die saambestaan van mense van verskillende rasse en kulture bykans onmoontlik is, met die handhawing van aparte geloofsgemeenskappe as die noodwendige gevolg. In dié verband tree Van Wyk in kritiese gesprek met Hervormde teoloë wat hierdie standpunt in die verlede bevorder het, onder andere J.M.G. Storm en H.P. Wolmarans, maar veral A.D. Pont (bl. 271-275). Van Wyk staan sterk afwysend teenoor die veridealisering van die Voortrekkers se vryheidsideaal, en die gedagte dat die NHKA histories en moreel verplig is om dié ideale te help verwesenlik.

Van Wyk verbind hierdie opvatting aan 'n nasionalistiesbepaalde geskiedenisvisie wat dikwels deur kerkhistorici voortgedra is (Van Wyk 1999:272-275). Die geloftes van Bloedrivier en Paardekraal funksioneer simbolies as die hoogste uitdrukking van die Afrikaner se uitverkore posisie, roeping en reg tot selfbeskikking. Hy toon aan dat hierdie geskiedenisvisie tipies is van die Romantiek, met sterk ondertone van 'n vooruitgangsgeloof en die droom van 'n utopie waar die Afrikaner vry van alle oorheersing kan leef. Van Wyk (bl. 273) meen dat dit 'n sekulêre geskiedenisvisie is, wat geen verband hou met ' $n$ eg Christelike verstaan van die geskiedenis nie.

Van Wyk wys verder daarop dat Pont se weergawe van die teokratiese ideaal, gegrond op Zwingli en Bullinger se gedagtes oor verbond, kinderdoop en corpus christianum, daartoe gelei het dat die NHKA as staatskerk van die Zuid-Afrikaansche Republiek (ZAR) veridealiseer is. Die Calvinistiese teokrasie is selde bevraagteken (Van Wyk 1999:275).

Van Wyk (1999:276) kom tot die gevolgtrekking dat hierdie dominante ekklesiologie met sy antropologiese, romantiese en teokratiese onderbou daartoe gelei het dat die NHKA 'n swak ontwikkelde sendingbewussyn vertoon.

Daarteenoor is daar natuurlik ook ander stemme, wat Van Wyk ook pertinent aantoon. Hy vind veral aansluiting by J.H. Koekemoer en F.J. van Zyl, wat openlik gewaarsku het dat die grense van die kerk en die volk nooit identies mag wees nie (Van Wyk 1999:277-278). Die kerk staan vreemd teenoor die volk. Die kerk kan nie die fakkeldraer van die Voortrekkerideaal wees nie.

In 'n slotparagraaf (Van Wyk 1999:279-284) kom Van Wyk daartoe om enkele kontoere te trek vir die toekoms. Hy meen 'aan die vooraand van die derde millennium is dit duidelik dat ons nie verder op ons ekklesiologiese tradisie in geheel kan steun vir oriëntasie vir die volgende dekades nie' (bl. 279). Nie net het die staatsbestel en die samelewing ingrypend verander nie, maar die sekularisasieproses en veranderende werklikheidsverstaan noop die kerk om te herbesin oor kerkwees in die een-en-twintigste eeu. Dit is op hierdie punt waar Van Wyk se voorliefde vir Luther se teologie na vore kom, as hy Luther se uiteensetting van die vryheid van die Christenmens gebruik as koersaanduider met die oog op die toekoms (bl. 280). Vir Luther (volgens Van Wyk) is die vryheid van die Christenmens niks anders nie as die vryheid om liefde teenoor die naaste te betoon. Dit sny enige vorm van rassisme, selfverheerliking en eiegeregtigheid by die wortel af. Dit laat die kerk opnuut sy diakonale en missionale roeping ontdek. Die kerk moet ophou om tyd te verkwis aan agterhaalde vryheidsideale, en eerder fokus om diensbaar in die gemeenskap te wees.

Hierdie profetiese oproep is sedert 2010 verwerklik, nadat die NHKA tydens die Algemene Kerkvergaderings van 2010, 2011, 2013 en 2016 ingrypende besluite oor apartheid, apostolaat, volkskerk en 'n nuwe ekklesiologie geneem het. Dit was die gevolg van talle publikasies en indringende gesprek oor kerkwees. Sonder twyfel was Van Wyk een van verskeie kritiese stemme wat bygedra het tot 'n verskuiwing in ekklesiologie en kerkbegrip in die NHKA.

Ter illustrasie van hierdie ekklesiologiese verskuiwing, haal ek aan uit Punt 5 van Besluit 1 van die 71e AKV (2016) van 
die NHKA, waar daar op 'n nuwe manier oor kerkwees gepraat word:

Ons glo dat God Drie-enig die Hervormde Kerk in die wêreld wil gebruik. Omdat die evangelie ons in beweging bring, wil ons, gehoorsaam aan Christus se opdrag in Matteus 28, dit ook met ander deel. Daarom wil die Hervormde Kerk missionaal leef. Dit doen elke gemeente deur die geloof in Jesus Christus met Woord en lied te vier, aan mense diensbaar te wees en te getuig van God se genade. Die manier hoe gemeentes dit doen, is om in alle eenvoud en nederigheid in die voetspore van Christus te volg en diensbaar te wees soos Hy ons leer. Ons is diep bewus daarvan dat ons onsself daagliks moet verloën, ons kruis moet opneem en dat ons heil nie te vind is in wêreldse mag of indrukwekkende strukture nie, maar in Christus self. Daarom word elke gemeente en lidmaat van die Hervormde Kerk opgeroep om in geloof en vertroue te luister na die roepstem van die Goeie Herder, en Hom te volg waar Hy ons ook al lei. (bl. 112)

Ekklesiologie as teologiese dissipline (en daarmee saam die kerk in sy konkrete bestaan) was van die begin van sy loopbaan vir Van Wyk belangrik. Sy meer sistematiese uiteensetting van ekklesiologie kom in vroeëre artikels na vore, onder andere Die gemeenskap van die heiliges (Van Wyk 1995), waar hy in gesprek tree met teoloë sedert die vroeë kerk, maar veral ook Brunner, Barth, Van Niftrik, Haitjema, Von Balthazar, Pannenberg en Moltmann. Hy toon aan dat die belydenis oor die gemeenskap van gelowiges oor eeue heen verskillende aksente verkry het. Reeds in 1995 waarsku Van Wyk dat die belydenis oor die gemeenskap van die gelowiges nie die NHKA daartoe moet verlei om ' $n$ bepaalde samelewingsorde te idealiseer nie (Van Wyk 1995:750).

Van Wyk se liefde vir die liturgie en die kerk blyk uit die volgende aanhaling (Van Wyk 1995):

Ek meen dat daar genoeg argumente aangevoer is ter ondersteuning van die tese dat die 'gemeenskap van die heiliges' ten diepste aan die Nagmaalstafel tot openbaring kom. 'n Lidmaat wat die een Sondag die 'gemeenskap van die heiliges' bely, maar die volgende Sondag nie aan die tafel van die Here gaan aansit nie, gee met hierdie optrede te kenne dat sy/haar belydenis oneg is. Die belydenis van die hart wat nie in praktiese handelinge omgesit word nie is nutteloos. Die kerk wat aan die hand van die Apostolicum glo en bely, maar die nagmaal verwaarloos, ondergrawe wat deur die kerk bely word. (bl. 750)

Die sterk historiese onderbou in Van Wyk se teologie, asook die waarde wat hy aan die kerklike belydenis heg, kom ook in 'n latere artikel oor die kerk duidelik na vore (Van Wyk 2013). In dié artikel pleit hy vir vernuwing in ekklesiologie; om te breek met verstarring sonder om te meen dat die voorbeeld van die Pinksterbeweging die ideaal is. Hy is van mening dat voortdurende kerkhervorming (ecclesia semper reformanda) nodig is (Van Wyk 2013:2), maar omlyn dit deur te pleit vir ' $n$ 'herontdekking van dit wat ons vergeet het of nooit van ons eie tradisie geweet het nie.' Hy waarsku teen 'n kerkbegrip wat 'sukses' vooropstel, en argumenteer dat die kerk altyd as kerk onder die kruis leef. Aansluitend by Plasger en Calvyn (bl. 3-5), toon hy aan dat die kerk nie identifiseerbaar is nie, maar tog ook empiries aanwysbaar is; dat die kerk in sy sigbare gestalte belangrik is en noodwendig binne bepaalde strukture moet funksioneer.

Van Wyk stem met Van den Beek saam dat die kerk as eskatologiese gemeenskap, as die volk van God, moet leef (Van Wyk 2013:4). Met aanhalings uit die Diognetos Brief uit die vroeë kerk, argumenteer Van Wyk dat die kerk 'n nuwe skepping is, 'n tertius genus wat onderskeibaar is van ander volke en kulture, en 'n unieke lewenswyse moet handhaaf.

Vir Van Wyk is die eenheid van die kerk belangrik. Op voetspoor van Calvyn (Van Wyk 2013:5), wys hy daarop dat die kerk die liggaam van Christus is; daarom kan die kerk per definisie slegs één kerk wees. Die uitverkorenes van God is aan mekaar verbind deur die Christelike geloof, hoop en liefde. Dit gee aan die kerk 'n eie en unieke geaardheid.

Met hierdie enkele voorbeelde is dit duidelik dat Van Wyk oor 'n periode van 20 jaar homself intens bemoei het met ekklesiologiese vraagstukke. Sy interpretasie van die kerklike belydenis, sy kennis van die kerklike geskiedenis en teologie, asook sy kritiese analise van die eietydse vraagstukke is opmerklik. Van Wyk is 'n kerklike teoloog wat erns maak met die kerklike belydenis en lewe, en sy nadenke oor kerkwees só aanbied dat dit vir die kerk diensbaar is. Sy ekklesiologiese insigte is tegelykertyd wyd en diep: Wyd in die historiese omvang daarvan, diep in sy skerpsinnige analise van die huidige diskoers en die wyse hoe hy teoloë vanuit verskillende tradisies in die gesprek inbring. Sy bydrae tot twee herskrywings van die Kerkorde van die NHKA (1997, 2016) is omvangryk en het daartoe bygedra dat die NHKA, wat ekklesiologie en kerkbegrip betref, op 'n veel vaster voet staan as tevore.

\section{Slotopmerkings}

Wanneer Van Wyk introspektief en krities reflekteer oor 'wie is die teoloog' en 'teologiebeoefening in die toekoms' (sien Van Wyk 2015b), is dit opmerklik dat hy nogmaals na Luther teruggryp vir opheldering. Hy vind aansluiting by Luther, wat van mening was dat elke gelowige Christenmens 'n teoloog is (bl. 2). Van Wyk verwys soos volg na Luther: 'Op 17 Januarie 1535, sê hy in 'n preek na aanleiding van Psalm 5:17: 'Omnes dicimur Theologi, ut omnes Christiani' [Ons is almal teoloë, soos ons almal ook Christene is].' Dit is só, omdat die Christelike geloof ook op die menslike rede aanspraak maak en die gelowige Christenmens uitnooi om oor die evangelie na te dink. Die teologie het as einddoel die verkondiging, maar tegelyk ook die hoor en verstaan van die prediking; ' $n$ gedagte wat ons by Barth terugvind, wat sy teologie ten dienste van die kerklike verkondiging beoefen het. Duidelik is dit ' $n$ standpunt waarmee Van Wyk homself vereenselwig.

Met hierdie enkele marginalia is 'n paar aspekte van Natie van Wyk se teologie eksemplaries op die tafel geplaas. Sy grootste bydrae is waarskynlik sy vermoë om reformatoriese teologie 
relevant en kontekstueel in die een-en-twintigste eeu aan die woord te stel; nie net in die Afrikaanse kerke nie, maar ook ander kerke wat in Afrika die evangelie verkondig.

\section{Erkenning \\ Mededingende belange}

Die outeur verklaar dat hy geen finansiële of persoonlike verbintenis het met enige party wat hom nadelig kon beïnvloed het in die skryf van hierdie artikel nie.

\section{Literatuurverwysings}

NHKA, 1997, Kerkorde, SENTIK, Pretoria.

NHKA, 2016, Notule van die 71e Algemene Kerkvergadering, Kerkargief, Pretoria.

Van Wyk, I.W.C., 1988, 'Die "verleentheid" van die teoloog voor die teodiseeprobleem', Hervormde Teologiese Studies 44(2), 450-461. https://doi.org/10.4102/hts.

Van Wyk, I.W.C., 1995, 'Die gemeenskap van die heiliges', HTS Teologiese Studies 51(3), 732-752. https://doi.org/10.4102/hts.v51i3.1430

Van Wyk, I.W.C., 1999, 'Wat glo ons van die Kerk', in D.J.C. van Wyk (red.), 20ste Eeu Hervormde Teologie, pp. 270-285, SENTIK, Pretoria.
Van Wyk, I.W.C., 2009a, 'Sickness and healing in Africa: A religious perspective', in N.C. van Wyk (ed.), Integrative healthcare: A guide to meet the needs of Africa, pp. 12-30, Juta, Cape Town.

Van Wyk, I.W.C., 2009b, 'A medical ethic for a pluralistic society', in N.C. van Wyk (ed.), Integrative healthcare: A guide to meet the needs of Africa, pp. 47-64, Juta, Cape Town.

Van Wyk, I.W.C., 2011, 'Finding a place for Jesus as healer in reformed mission in Africa', HTS Teologiese Studies/Theological Studies 67(1), Art. \#864, 1-8. https:// doi.org/10.4102/hts.v67i1.864

Van Wyk, I.W.C., 2013, 'Die Hervormde Kerk: Soekend na 'n weg tussen ekklesiologiese verstarring en innovasie sonder tradisie', HTS Teologiese Studies/Theological Studies 69(1), Art. \#1999, 1-11. https://doi.org/10.4102/hts.v69i1.1999

Van Wyk, I.W.C., 2015a, 'Rudolf Bultmann se verstaan van vryheid', HTS Teologiese Studies/Theological Studies 71(3), Art. \#2895, 1-8. https://doi.org/10.4102/hts. v71i3.2895

Van Wyk, I.W.C., 2015b, 'Martin Luther en teologiebeoefening in die toekoms', HTS Teologiese Studies/Theological Studies 71(3), Art. \#3070, 1-8. https://doi.org/ 10.4102/hts.v71i3.3070

Van Wyk, I.W.C. (ed.), 2017a, 'Nadenke oor 500 jaar se Reformatoriese teologie', HTS Theological Studies/Teologiese Studies, Supplementum 11, 73(5), 1-250. https:// doi.org/10.4102/aosis.2017.hts11

Van Wyk, I.W.C., 2017b, “'Die barmhartige God, regverdiging en goeie werke deur Luther," in "Nadenke oor 500 jaar se Reformatoriese teologie", , HTS Theological Studies/Teologiese Studies, Supplementum 11, 73(5), a4558. https://doi.org/ 10.4102/hts.v73i5.4558

Van Wyk, I.W.C., 2017c, "'Martin Luther en Johannes Calvyn oor die Christelike vryheid," in "Nadenke oor 500 jaar se Reformatoriese teologie"', HTS Theological Studies/Teologiese Studies, Supplementum 11, 73(5), a4557. https://doi.org/ $10.4102 /$ hts.v73i5.455 